\title{
The Role of Independent Human Rights Institutions for Children (IHRICs) in Africa in Raising Awareness about Children's Rights among Children
}

\author{
Hilda Kalekyezi Nankunda ${ }^{1, *}$, Nigel Thomas ${ }^{2}$ \\ ${ }^{1}$ School of Social Work, University of Central Lancashire, UK \\ ${ }^{2}$ School of Social Work, Care and Community, University of Central Lancashire, Preston, UK
}

Copyright $\odot 2016$ by authors, all rights reserved. Authors agree that this article remains permanently open access under the terms of the Creative Commons Attribution License 4.0 International License

\begin{abstract}
This article discusses implementation of the UNCRC 1989, by African Countries. It explores ways of using Independent Human Rights Institutions for Children (IHRIC) in Africa, to increase awareness of children's rights among children so that they (children) can participate and even lead in realizing their own rights. It is based on a qualitative design in two phases. Phase 1 was a documentary review of periodic reports from 25 African signatory states. Content analysis revealed that IHRICs by African Countries are not independent according to the recommendations of the General Comment No. 22002 which reverberates with the Paris Principles 1993. Phase 2 Field work was conducted in two districts and two communities in Uganda. Action Research approaches were employed to 72 participants including 21 children aged 10-15 years. Focus Group Discussions were conducted with children, Dialogue Meetings for the community facilitated by children and Key Informant Interviews. It was found that children can articulate their rights and contribute to decisions that affect them. This article suggests that States Parties in Africa should support implementation of UNCRC by availing funds to the HRIC to fulfill their functions. Emphasis should be on raising awareness about children's rights and involving children in decisions making, planning and policy development activities.
\end{abstract}

Keywords Children, Rights, Institutions for Children, Action Research Top-down Implementation, Child Participation

\section{Background}

\subsection{Introduction}

It has been 25 year since international legislation on children's rights the United Nations Convention on the Rights of the Child (UNCRC)1989 [1] came into force. The UNCRC is applauded as the most widely and rapidly accepted human rights treaty in history. It is the world's first international legal instrument on children's rights whose drafting lasted ten years of negotiation among government delegations and intergovernmental organizations [2]. The UNCRC gives children rights to freedom of expression, association, thought, conscious and religion, protection against abuse and violence, enjoyment of the highest attainable standard of health, education, rest and leisure, protection from economic exploitation and hazardous work $[3,4$, and 5$]$.

However, majority of children in the global south and Africa in particular remain disadvantaged, vulnerable and unable to access children's rights. This has been attributed to poverty and bad governance inherent in these countries $[6,7$, and 8]. The Committee on the Rights of the Child recommended the establishment of IHRIC to facilitate implementation in the General comment No. 2 (2002) [9]. Their roles include influencing legislations and policy development as well as raising awareness about children's rights among children which resonated with the Paris Principles (1993)[10].

This article is about the role of the Independent Human Rights Institutions for Children (IHRICs) in Africa in raising awareness of children's rights among children and the potential for these institutions to engage directly with children. The main focus of the article is on Articles 4 and 42 which provided for children to be informed about their rights by governments and to be engaged so that they contribute to decisions that affect them as stated in Article 12. Studies have revealed that IHRICs are instrumental in promotion and protection of children's rights $[11,12,13,14,15$, and 16] and the awareness raising role of the institutions is an important aspect in realization of rights for children by influencing demand and access to rights. Therefore, exploring raising awareness about children's rights and the involvement of 
children in decisions that affect them in the communities are key ways of assessing the impact of children's rights legislation.

This article seeks to contribute to the knowledge about governments' role in establishing and facilitating IHRIC to engage with children and get them to know their rights, and their voices included in planning, policy and other decisions.

\subsection{Specific Objectives}

1. To contribute to knowledge about implementation of Article 42 of the UNCRC 1989, and response to the General Comment 2. 2002.

2. To illustrate the experience of engaging with children to solicit their views about their rights

This article is intended to contribute to knowledge about African Countries challenges and experience with implementing international legislations. It deals with the management of top-down approaches in policy and planning. The article suggests a bottom-up approach in implementing projects by soliciting contribution from the weak and marginalized [17]. It illustrates creating space and harnessing their experiences with the UNCRC through action research.

\section{Literature Review}

\subsection{Implementing International Legislations}

It is becoming increasingly important to recognise human rights for different groups of people. Children's rights also need to be realized through well designed rights based programmes strategy. Studies about the effectiveness of global governance in ensuring better welfare for children have observed some weakness in the system. Munroe et al. [18 further draws attention to the paradox in the implementation of the UNCRC as not a straight forward matter of top down influence but management of a complex global / national dynamics with all its uneven development, levels of influence, range of institutional actors and varying length of time involved. Moreover, the history of colonialism and the emergence of counter-hegemonic form of the Third World are observed challenges to global governance [19].

Munroe et al. [20] further criticized the work of the Committee that working through global directives and national compliance through General Comments is not very effective. This resonated with the weakness of the top-down approaches [21], which focuses on the perspectives of the central decision makers neglecting other actors. According to Munroe et al. [20b], the best strategy to achieve better results for children would be dialogue that allows governments to articulate their concerns as part of coherent and progressive global agendas for children, as well as allowing the UNCRC Committee to prompt national development in compliance with the Convention. Andrea [22] identified funding as a challenge to implementation of international human rights governance in developing countries however, there are other factors including lack of political will, inadequate capacity and expertise for implementing rights.

True recognition of children's rights requires implementation in practice through legal reforms and policy formulation. Children's rights have been legislated, but law enforcement, implementation and monitoring are inadequate $[23,24]$. As observed by O'Neill [25] which States Parties should remember, un-implemented, partially implemented or badly implemented laws and policies do children more harm than good. Rights must translate into service and resources if they are to benefit children. This is of particular significance in the African context because of the social, economic and political factors that pose a challenge to realisation of children's rights [26]. African Countries record progress in some social economic indicators for children. For instance, Uganda was reported to have made good progress in the Millennium Development Goals (MDGs) performance [27]. On the contrary, the ACPF [28] revealed that children in Africa have remained poor and need special focus in global plans. This contradiction may be interpreted for inadequate awareness about children's rights and targeting of children in development programmes.

\subsection{Problem the Article Seeks to Address}

This article endeavors to uncover challenges that could be hindering the implementation the international legislations for children. It is about the experience of IHRICs in Africa in implementing the UNCRC, and explores ways in which these institutions would have children's voices in their work through direct interaction with children as observed in literature $[29,30]$. This has not been done in Africa and therefore this study applies the theories to communities in Uganda through action research approaches and specifically a dialogue meeting facilitated by children. It illustrates that children will communicate to parents, guardians, and community leaders their perception of rights and violation of rights in the community if they are given opportunity. The article also recognizes the importance of respect and understanding of African traditions and culture in the implementation of UNCRC as was found in the writings of [31, 32, and 33]. This should be done to promote bottom-up approach in addressing children's rights.

After 25 years of the UNCRC 1989, the human rights situation of majority children especially in Africa have remained poor $[34,35,36]$. The studies on implementation of the CRC in Africa [37, 38, and 39] did not take into account the role of government institutions like the IHRIC in raising awareness about children's rights. This article therefore, seeks to contribute to the knowledge about governments' role in establishing and facilitating IHRIC to engage with children and get them to know their rights, and their voices included in planning, policy and other decisions. 


\subsection{Respect for Children's Voice}

Steward [40] observes that child participation is closely linked and interdependent with civil and political rights. Participation of the rights holder is a core element in any human rights based approach promoted in various contexts at national regional and international levels. For instance, children should participate in the development of legislation, public policy making, development strategy, poverty reduction strategy and other activities (40 pages 15 ). Child participation brings children's perspectives into the development processes. Therefore, true recognition of children's rights requires implementation in practice through legal reforms and policy formulation that promotes their inclusion. It has been found that children's rights have been legislated, but law enforcement, implementation and monitoring are inadequate [41, 42, 43, and 44]. Moreover, in spite of UNCRC adaptation and incorporation into local laws and policy, violation and child abuse incidents are still inadequately managed. Perpetrators of abuse are sometimes given light sentences while others remain unpunished probably due to the diverse nature of abuse and neglect across cultures. This discourages people from reporting abuses and all forms of children's rights violation [45]. However, in Africa, the culture of silence and some traditions also affect reporting of violation of rights. Inadequate services lead to unfulfilled rights as Federle [46] observed awareness of rights promotes better protection of children. This is of particular significance in the African context because of the social, economic and political factors that pose a challenge to realization of children's rights [47], and besides, the situation of children in Africa has not improved $[48,49,50]$.

Consulting children has been practiced by adults due to fears that children will have divergent ideas. However, as found by some authors, listening to children does not mean doing everything they ask for or giving children's views more weight than adults. It means more respectful listening and taking into account children's perspectives which is empowering [51, 52]. However, treating children as equal participants could be dangerous for children by exposing them to responsibilities that are beyond their capacities. As suggested by Fortin [53] children need to be guided in some decisions about time out late in the night, speed discipline on a busy road, nutrition, diet and exercise. Arguably, adults should have influence on decisions about career and other issues of life that have long term benefits which children may not readily discern. Children who experience respect for their views and are encouraged to take responsibility for those decisions they are competent to make will acquire the confidence to challenge any abuse of their rights.

In recent years, it has become clear that bids to serve children's best interest are themselves capable of harming children [54] and also hindering children's emancipation [55]. This could explain why implementers of children's program are sometimes hesitant to give them some freedoms. Sometimes adults are not aware that children's voices are being silenced when they are unable to represent themselves.
As suggested by [54b] children's self-representation is both the first and last line of defense against the inadequacies of adults' institutions; the first and last means to decrease their vulnerability to harm and exploitation. This alludes to the need for parents/guardians, community leaders and policy makers to solicit children's views on matters in the family, community and programs implemented at various levels. Lundy [56] presents four factors that make children's participation in matters that concern them meaningful: 'Children must be given opportunity (space) to express a view, children must be facilitated to express their views (voice), there must be someone to listen to children's views (audience) and that the views must be acted upon as appropriate (influence). This process was applied in the field study through action research' [56 p. 933].

Experience of involving children in development activities is demonstrated in the Child Reporters project in Orissa, India [57]. This illustrated a successful process of listening to children to the highest level of participation, whereby the youth initiate and share decisions with adults [58]. Under the Child Reporter project, children from poor tribal communities effectively influenced plans by sharing their perspectives from their schools, homes, village, and government. The processes involved attending training in basic news reporting skills involving them in discussions regarding development, and inspiring their thinking on development issues. Children developed topics and presented reports to high level officials including Chief Minister, the Senior State Secretaries for education, women and child development, the secretary media and other stakeholders. Children's work and processes was taken seriously and was recommended for other States [59]. Children reported on development issues in their villages, monitored and communicated about the process of development and short comings. These experiences illustrate that informing children, consulting children, giving them opportunities to take initiatives and sharing in actual decisions making is the middle levels of child participation which should be the goal of stakeholders implementing the UNCRC, and it can be effective.

\section{Research Design}

\subsection{Design}

This article is based on a qualitative research design which according to Creswell [60] is a systematic subjective approach used to describe life experiences and give them meaning. The article is based on a study conducted in two phases. A phenomenological field research design $[61,62]$ was applied. Epistemologically, phenomenological approaches are based on a paradigm of personal knowledge and subjectivity to emphasise the importance of personal perspectives, reflection and interpretation. The researchers elicited deeper understandings of children's perspectives and explored their experiences with children's rights both at home and in their communities. Qualitative methods used in 
the study included Focus Group Discussions (FGDs), Key Informant Interviews (KII), and Dialogue Meetings (DM). In addition, drawing, resource mapping and observation were engaged in for non-verbal responses during group activities and meetings.

In Phase 1 a documentary review of periodic reports from purposively selected 25 African Countries to the Committee on the Rights of the Child. Their progress regarding establishment of IHRIC to oversee the implementation of UNCRC was done. The review revealed that African countries have IHRIC of various categories as shown in Table 1 However, these institutions did not report on awareness raising activities about children's rights. This led to field research in Uganda as a case study in Phase 2. Children, community members and key stakeholders participated.

\subsection{Setting}

The documentary review covered 25 countries purposively selected from 56 countries on the African continent. these included, the Arab North, represented by Tunisia, Libya, Morocco, Egypt and Sudan; West Africa represented by Guinea Bissau, Nigeria, Ghana, Sierra Leone and Senegal; East African countries including Uganda, Kenya, Tanzania, Rwanda, Burundi and Ethiopia; Southern Africa countries including South Africa, Swaziland,
Zimbabwe and Malawi ; South Western Africa represented by Namibia and Angola; the Democratic Republic of Congo (DRC) in Central Africa and the Islands in the Indian Ocean including Mauritius and Madagascar.

In Phase 2, Field research was conducted with children in a peri-urban and a 'deep rural' community very far from the capital city. In Wakiso District (central region), the field study was conducted in Nabaziza village (Nsangi Sub-County, Kyengera parish), $13 \mathrm{~km}$ from Kampala city. In Rukungiri District (Western Uganda), about $400 \mathrm{~km}$ from the Kampala, study participants were selected from Kanombe village (Buyanja Sub-County, Nyabiteete Parish).

\subsection{Participants in Field Research in Uganda}

Children of this age (10-15) were also likely to be exposed to more information through interaction with their community. Parents, guardians, Local Council leaders, religious leaders and teachers living in the community $(\mathrm{n}=25)$, stakeholders at Sub-County $(\mathrm{n}=03)$, District $(\mathrm{n}=06)$ and National level $(n=17)$ were also consulted to share their experience and views about awareness of children's rights and institutions that are in place, to serve the interests of children. During this process, I was able to interact with a total of 72 participants as shown in Table 2 following.

Table 1. Countries and types of reports analyzed

\begin{tabular}{|c|c|c|c|}
\hline Country Reports & NGO Reports & Concluding Observations & $\begin{array}{c}\text { Summary Report/General } \\
\text { Comments }\end{array}$ \\
\hline $\begin{array}{c}\text { Tanzania, Nigeria, Congo DRC, } \\
\text { Malawi, }\end{array}$ & $\begin{array}{c}\text { Guinea- Bissau, Swaziland, } \\
\text { Tanzania, Burundi, Kenya, } \\
\text { Kenya, Liberia, Egypt, Tunisia, } \\
\text { Burundi, Namibia, Uganda, } \\
\text { Ghana, Swaziland, Madagascar, } \\
\text { Rwanda, Angola, Morocco, } \\
\text { Ethiopia }\end{array}$ & $\begin{array}{c}\text { Zambia, Congo, Madagascar, } \\
\text { Rwanda, Morocco, Malawi, } \\
\text { Tanzania, Sudan, Zimbabwe, } \\
\text { South Africa, Uganda, Liberia, } \\
\text { Ghana, Burundi, Angola, } \\
\text { Ethiopia, Kenya, Congo DRC } \\
\text { Leone }\end{array}$ & $\begin{array}{c}\text { Human Rights annual Report } \\
\text { General Comment No. 2 2002 } \\
\text { Special report } 1370 \text { on } \\
\text { implementation }\end{array}$ \\
\hline 18 reports & 12 reports & 18 reports & 5 and more \\
\hline
\end{tabular}

Table 2. Distribution of participants in the study

\begin{tabular}{|c|c|c|c|c|c|}
\hline Districts & Children 10-15 years & $\begin{array}{c}\text { Community } \\
\text { dialogue }\end{array}$ & Sub county & District & National level \\
\hline Wakiso - Nsangi - Kyengera & $08(4$ male $)$ & $12(5$ male $)$ & $02(1$ male $)$ & $03(2$ male $)$ & $17(7$ male $)$ \\
\hline $\begin{array}{c}\text { Runkungiri - Buyanja } \\
\text { Kanombe }\end{array}$ & $13(7$ male $)$ & $13(5$ male $)$ & $01(0$ male $)$ & $03(2$ male $)$ & 17 \\
\hline Total & 21 & 25 & 03 & 06 & 17 \\
\hline \multicolumn{7}{|c|}{$\mathbf{7 2 ~ p a r t i c i p a n t s ~}$} \\
\hline \multicolumn{7}{|c|}{}
\end{tabular}


Participants' selection was purposive in order to identify and involve children in their communities. This was during school holidays and all children were in primary school, except for two children in secondary school in their first year, Senior One ${ }^{1}$.

\section{Procedure}

\subsection{Data Collection and Research Methods}

Field research was an illustration of involving children in decisions that affect them and exploring channelling their views from the communities to national level to influence policy. Data were collected from children ages 10-15 in group discussions which were conducted in teams of two or five children, guided drawing activities and Focus Group Discussions (FGDs). The children presented their two- days' work to parents, guardians, community members and local leaders at a Dialogue Meeting (DM). A summary of this experience and children's perceptions of rights were presented to selected stakeholders at sub-county, districtand national-level as Key Informant Interviews (KII) respondents. Interviews with these officials provided opportunities to share the perceptions of children about their rights, to seek clarification on the situation observed at a community level, and also to elicit recommendations and policy suggestions as to how to raise awareness successfully about children's rights amongst children. Some KII participants shared their reports and other primary sources on children's rights in the country.

Data were collected during two visits to Nabaziza community and Kanombe village in the period July-December, 2013 and again in March 2014. During the first two weeks of October 2013 data were collected from Nabaziza community; during the last week of October and the first two weeks of November 2013 data collection was done in Kanombe. KIIs were also conducted during this time whilst observing for any negative reactions that could affect children as a result of their participation in the research. The first visit during the months of July, August and September 2013 covered planning activities with leaders at National and community levels, introduction to the communities, and mobilisation for participation in the action research. The second visit, which was aimed at finding out whether communities had learnt anything from the research to improve the situation of children, revealed that communities were interested in extending discussions about children's rights as part of their Local Council ${ }^{2}$ meetings.

The research team also included one National Council for

\footnotetext{
${ }^{1}$ In the Uganda school system, the first seven years are devoted to primary schooling, and then pupils join secondary school for four years and later move on to years in high school or advanced education before joining University. However, there is another path at every level for those that wish to pursue technical training for various reasons.

${ }^{2}$.Local Council (LC) is the lowest administrative level in every village. An LC comprises about 10 households. The structure goes up to district level, where we have the LC.V chairman.
}

Children (NCC) stakeholder staff member as a National partner in Nabaziza, and the Sub-County community development officer in another village, Kanombe, as District partner. The two officers assisted with note taking during the discussions. They were purposely involved to gain first-hand experience of the process of involving and learning from children.

\subsection{Selection of a Country Case Study Uganda}

A case study Country focused on Uganda to study how institutions could be working to raise awareness about children's rights and through their oversight position regarding UNCRC implementation. Notwithstanding the challenges of realizing children's rights, there are several reasons that make Uganda a good choice for case study. Uganda has a decentralized government structure which favors participation.

Furthermore, Uganda has the youngest population in the world, with $78 \%$ of the population below 30 years [63]. Studying institutions for children and awareness of rights in this Country is necessary to inform plans and programs for empowering young people and harnessing their potential to make a positive contribution to national development. I am Ugandan and have worked with child-focused organizations and the National Council for Children (NCC), which is a government semi-autonomous institution for children affiliated to the Ministry for Gender Labor and Social Development (MGLSD) and a local partner in the study.

\subsubsection{Selection of the districts and communities}

Selection of communities was also purposive. The study was intentional in covering experiences of children in peri-urban $13 \mathrm{~km}$ and deep rural community $240 \mathrm{~km}$ from Kampala the capital city. This decision was intended to find any differences in children's perspectives of their rights. The peri-urban represents partially city and small town lifestyles for children. Language is a great asset in qualitative research for effective facilitation of discussions [64] was also a special consideration since the study was with children in the community and community members who are not likely to understand English. I am fluent in both Luganda which is spoken in Nabaziza (Central) and Runyankole-Rukiga spoken in Kanombe (Western). I stayed with family to minimise accommodation and transport cost as a practical factors that were considered in the selection of Districts and villages to make data collection a success.

\subsection{Focus Group Discussions (FGDs)}

In Nabaziza (a), on the first day the group had 12 participants and on the following days only 8 ( 4 boys and 4 girls) children participants turned up for the meeting. In Kanombe (b), the group had 13 (6 boys and 7 girls) children participants who consistently attended the sessions. The classroom was much bigger and arranged in a semi-circle to allow eye contact during interaction. Children accepted to 
discuss as a mixed group of boys and girls throughout the exercise. They had the same level of knowledge since they came from the same communities, age group and level of education (primary school education, only one out of school and one in secondary school, senior 1). Children were assigned numbers that were recorded with the village assigned letter (a) Nabaziza or (b) Kanombe.

Different drawings from the groups showing community facilities known to children stimulated the group to discuss children's rights. The drawings served as ice-breakers and also depicted the children's awareness of their environment and useful resources in it. The reflections, interpretation and discussion of what different groups drew enhanced rapport with children and enthusiasm for participation in other activities. Children introduced the concept of 'rights' from drawings.

The distribution of children participants in the research by age, gender and level of schooling is shown in Table 3.

Children were still in school, except one boy who enrolled dropped out due to lack of school fees. The level of schooling did not affect their participation during group activities since they were same age group. I moderated the interaction and took note of issues that were raised in the discussions.

\subsection{Key Informant Interviews (KIIs) / Discussions}

Key Informants Interviews were conducted for key stakeholder implementing the UNCRC from government department at Sub-County, district and National level and Civil Society Organizations (CSO).

\subsection{Observation}

Observation is not only about watching people $[65,66]$. According to Mason [66], it refers to methods of generating data which involve the researcher immersing herself in a research setting. Observation uses the five senses but in this study it was limited to some non- verbal reactions during interaction in all activities like laughter, and unanimous affirmations which were noted and probed for explanation from the children. Discouraging reactions within the group work process that were observed were quickly quelled to avoid group distraction..

Table 3. Distribution of children participants showing Age, gender and Education

\begin{tabular}{|c|c|c|c|c|c|c|c|c|c|}
\hline Age & \multicolumn{2}{|c|}{10} & \multicolumn{2}{|c|}{11} & \multicolumn{2}{|c|}{12} & \multicolumn{2}{|c|}{13} & \multirow{2}{*}{ Educ. } \\
\hline \multirow{9}{*}{$\begin{array}{c}\text { Nabaziza } \\
\text { (a) }\end{array}$} & M & $\mathbf{F}$ & M & $\mathbf{F}$ & $\mathbf{M}$ & $\mathbf{F}$ & $\mathbf{M}$ & $\mathbf{F}$ & \\
\hline & $4 a$ & & & & & & & & No. chn. \\
\hline & $7 a$ & & & & & & & & P. 6 \\
\hline & & $2 \mathrm{a}$ & & & & & & & P. 5 \\
\hline & & $8 \mathrm{a}$ & & & & & & & P. 5 \\
\hline & & & $1 \mathrm{a}$ & & & & & & P.7 \\
\hline & & & $5 \mathrm{a}$ & & & & & & P. 6 \\
\hline & & & & $6 a$ & & & & & P.7 \\
\hline & & & & & & $3 a$ & & & P. 3 \\
\hline \multirow{14}{*}{$\begin{array}{l}\text { Kanombe } \\
\text { (b) }\end{array}$} & $2 b$ & & & & & & & & P. 6 \\
\hline & $7 b$ & & & & & & & & P. 5 \\
\hline & $9 \mathrm{~b}$ & & & & & & & & P. 3 \\
\hline & & $1 \mathrm{~b}$ & & & & & & & P. 6 \\
\hline & & $5 \mathrm{~b}$ & & & & & & & P. 6 \\
\hline & & $13 b$ & & & & & & & P.1 \\
\hline & & & $4 b$ & & & & & & P. 5 \\
\hline & & & $11 \mathrm{~b}$ & & & & & & P. 4 \\
\hline & & & & $3 b$ & & & & & P. 2 \\
\hline & & & & $6 \mathrm{~b}$ & & & & & P.7 \\
\hline & & & & & $10 \mathrm{~b}$ & & & & S.1 \\
\hline & & & & & & $8 b$ & & & P. 5 \\
\hline & & & & & & & $12 b$ & & S.1 \\
\hline & 5 & 5 & 4 & 3 & 1 & 2 & 1 & 0 & 21 \\
\hline
\end{tabular}




\subsection{Dialogue}

Dialogue meetings (DM) for children with parents, guardians and community members $(n=25)$ were held in the two communities. The DMs enabled were facilitated by children as they presented their collective views about their rights. For the first time the communities discussed children's rights violation in their communities. These meetings were a forum for sharing and expounding on the failures to protect children from abuse in two villages. Children volunteered to present their perceptions of rights reading from the flip-charts which were pinned on the walls in meeting rooms for viewing. A fundamental aspect of this study was giving children and community members' space in participatory research that enables marginalized people to share and analyze their knowledge of life and to act $[67,68]$.

\section{Research Duration}

Documentary review and analysis of country reports started in May 2012 as part of literature search. A preliminary report identifying gaps informed the plans for Phase 2 and field research in Uganda. Field work plans and data collection started in June 2013 and lasted a period of six months in Uganda. The months of July, August and September were devoted to preparations activities including securing ethical approval from the University, discussions with partners in Uganda and orienting the local partner on the research tools, selecting communities, and reconnaissance visits the communities, planning and identifying venues with community leaders and finally data collection. During the first two weeks of October, data were collected from Nabaziza (a) community; during the last week of October and the first two weeks of November data collection was done in Kanombe (b) community. I stayed in each of the villages for another week after data collection interacting with community members. KIIs were also conducted during this time whilst observing for any negative reactions that could affect children as a result of their participation in the research. The NCC and the communities were visited the second time for one month in March, 2014. Preliminary draft reports were presented to the communities.

\section{Ethical Considerations}

Transparency was a hallmark of the study from preparation stage to the end of the research process. The research proposal was shared with local partners in the Ministry for Gender Labour and Social Development (MGLSD) and the NCC as local partners in the study. The participation of children and other stakeholders was voluntary. The children were informed that they could opt out of any activity for any reason and at any time. Informed consent was obtained through the community leaders, the LC chairmen. They also mobilised the participants and identified neutral secure venues for the meetings in the community to ensure privacy and confidentiality. To maintain confidentiality, only the principal investigator retained the names and identifying information of the participants, and did so in a secure and locked location.

\section{Data Analysis}

Qualitative data analysis methods were used. Content analysis was adapted in Phase 1 of the study. Country experiences with awareness raising activities were also traced in the review and recorded in a matrix under main headings including government effort to establish institutions, recommendation and observations by the Committee on the Rights of the Child and issues that conflict with the UNCRC 1989 [69]. Thematic analysis was guided by research questions raising awareness in the States Parties, children accessing institutions for redress in case if rights violation and participating in plans and decision making.

Analysis of data from Uganda in Phase 2 used inductive approach to generate interpretations and justify explanations using similar circumstances and children's perceptions of their rights. The analysis reflected upon children's experiential world of their rights which was shared in Focus Group Discussions. This approach was also applied to responses from parents / guardians and community members and key informant interviews as suggested by Gibbs [70], respecting their views and comments. Data from KII were organized in a matrix under key themes that emerged, interpreted and discussed.

\section{Findings from the Study}

\subsection{The Role IHRIC and Involvement of Children in Decision Making}

States parties have different ways of addressing children's rights for better welfare of their children. They are implementing the UNCRC through unique HRICs structures in terms of names and levels of operations and these institutions lack specific focus on children. Institutions identified include: Ombudsman, National Councils, Human Rights Commissions, National committees and Directorates. Other forms included Observatory and traditional leaders which are also supporting structures for effective implementation of children's rights. The documentary review revealed that African Countries have made progress in domesticating the UNCRC into national legislative systems; policies and plans for action have been developed. Whereas reports revealed a lot of awareness-raising activities about children's rights especially by Civil Society Organizations (CSOs), they did show whether these activities were monitored and they do not seem to have adequately targeted children. The role of CSOs was observed 
to be increasingly prominent in implementing specific interventions where they have advantage over government institutions.

Most Countries reviewed had National level offices only except for Angola, Egypt, Congo and Morocco which have children's rights institution structures at lower level. The roles and mandates of these national institutions did not extend to lower levels of administration and to communities and children. Countries with structures like Namibia were reported to have duplication of roles that need to be reviewed [71], while structure of elders as advisers in Ghana seemed to be ineffective in advocating for strengthening of the Ghana institution, which was reported to have closed [72]. The inherent technical and financial weakness of these institutions, also affects their independence in protecting, promoting and monitoring children's rights in these countries. The observations and recommendations to state parties from the Committee suggest increasing budgets and ensuring recruitment of competent staff.

Institutions found in 25 African countries were not independent except Mauritius Ombudsperson.

However, UNICEF [73] gives nine IHRIC in Sub-Saharan Africa. The Mauritius Non-Government Organization (NGO) [74] report revealed that it was a separate unit unlike other IHRIC in other Countries which are located under a government ministry. For instance, Ministries of Gender; Family and Population; Community Development; Social Services; Equity and Welfare and Social Cohesion. Burundi has the Ministry of National solidarity and Human Rights [75], Sudan Ministry of Interior Department of Child Protection [76] and in Swaziland the Ministry of Health and Social Welfare as a lead Ministry (NGO report [77]. Locating children issues under such Ministries seems to imply that the main/ mother ministries will support children's rights in their activities. It may not be necessary to emphasize the 'independence' of the institution for children but rather, emphasis should be placed on a strong and well-funded institution with technical capacity to influence other sectors.

The review found that 'IHRIC' do not engage with children and are not raising awareness about children's rights among children. States Parties reported that CSOs were raising awareness about children's rights on behalf of government. In Uganda, CSOs contributed greatly in raising awareness about children's rights, targeting both adults and children [78, 79, and 80]. However, focus on children was unclear in both reports from Uganda and Sierra Leone, apart from Child Rights Clubs in some schools in Uganda. The Committee was concerned about insufficient measures to disseminate and raise awareness of International Human Rights standards, including the CRC [81]. In Nigeria NGOs were reported to be instrumental in advocating for children's rights, while in Angola lack of transparency and accountability to non-member NGOs was reported $[82,83]$.

The field research confirmed that children have the capacity to contribute to decisions, plans and programmes in the community, as well as communicating to the elders in the community their rights if they are given opportunity. Therefore, children's views can be included in plans, policies and decisions in their communities. It was further revealed that children have potential to protect the rights of other children. They identified For instance, they made reference to the plight of the orphan child and discrimination against disabled children in play and games (FGD). It is worth noting that engaging in discussions about children's rights enhanced awareness about children's rights among stakeholders including children. Communities revealed inadequate knowledge about structures and institutions that promote and protect respect for children's rights. At the dialogue meetings, inadequate awareness raising activities about laws that protect children against violation of rights was uncovered. The family, church and Local Councils institutions were influential in protection and promotion of children's rights through service delivery within their limited resources. The Police was also mentioned as an institution providing security to children.

The community member's words resonated fears of parents and other adults regarding children's rights. There is a misconception about children's rights that they make children disrespectful and irresponsible at home and in the community which was also found in Cheney [84] conversations with the UNICEF staff at that time revealed that children's knowledge of rights could lead to disharmony within the family. I would interpret misconception to a poor approach to the communities and poor presentation of children's rights messages and emphasizing UNCRC Articles that do not relate to local situations. For instance, when talking to parents about children's rights put emphasis on articles $4 ; 18,26,29$ that commit government to support poor families to fulfill the rights of children and addressing the parents burden in supporting children, would have been more acceptable to parents. Parents needed more time and specific focus as key duty-bearers in realizing children's rights.

Key stakeholders implementing children's rights in Uganda from CSOs, Government institutions and departments revealed that implementation of international legislation at local level was more complicated than assumed. Government policies are not simply implemented without questioning the background and origins of new ideas which may not be clear. This posed challenges related to appreciating new ideas, and passing on information to beneficiaries. Moreover, inadequate understanding of children's rights makes it difficult for them to interpret concepts to local people and to convince them about the benefits they bring to the lives of children.

The responses from key stakeholders were consistent with what children and community members contributed to the study. The results showed the need to have institutions that promote children's rights accessible to children. It was evident from the responses that communities and key stakeholders had inadequate capacity to effectively support implementation of children's rights. This could be attributed to the general lack of awareness and appreciation of basic 
concepts such as child participation and soliciting children's voices which were the focus of this study. Besides, stakeholders were constrained in their work in regard to protection of children against abusers and management of reported cases. Even when it could be possible to enforce provisions of the UNCRC, for instance, to protect children against violation of their rights in the community and family, the government had no support systems for safe custody of children after they had reported members of the community or family member. Institutions for children therefore, were not fully established and facilitated to serve children effectively with such critical gaps in service provision.

Action research with children and community members in Uganda clearly demonstrated that children have good information that can inform policy and programme activities. The tactics for engaging with children require interest and time. This research method was chosen to demonstrate how IHRICs could solicit children's views for incorporation in decisions that affect them may be applied elsewhere in Uganda and Africa. The aspect dialogue meeting with children communicating to parents, guardians and community leaders their perspective of rights as children, and adult's members of the meeting taking children's issues generated by children seriously. Information from children's activities and FGDs was presented by children at the community dialogue meetings and needs to be scaled-up. The approaches and procedures used with children to explore children's rights are applicable to other development concerns in which children's voices need to be heard. Key features of the process included consultation of children by engaging them in appropriate activities, children discussing their group and individual work as part of interpretation analysis and consensus on what matters to them and dialoguing with community leaders and other people involved in the development processes.

However, during the field research in Uganda, key stakeholders for children's rights revealed that they are not fully convinced about children's potential to contribute to activities that affect them. Some officers in decision making positions at various levels lacked experience and skills in working / involving children. This was implied in the recommendations from the respondents that, "even our bosses need to be trained in children's rights" (KII). This might be the reason children are not given opportunity and platform in committees and other activities to empower them to contribute to decisions in their communities even when they are also affected. Key informant respondents affirmed that children's rights were violated at various levels and that services providers had financial constraints. This corroborated with Andrea [85] finding in Bangladesh regarding funding of human rights and governance.

\section{Discussion of the Findings}

The review uncovered that there are children's rights institutions in African Countries under various categories.
These were not accessed by children to voice their concerns and to participate in their activities. 'IHRIC' in Africa serve other purposes that support promotion, monitoring and protection of respect for children's rights as confirmed through field research in Uganda. Country reports to the Committee on the Rights of the Child analysis revealed that they do not purposely raise awareness about children's rights among children. However, reports gave information about other stakeholders in the implementation of the UNCRC including CSOs that were engaged in awareness raising activities. NGOs in some countries in Africa have a working understanding with States Parties to complement government efforts to reach remote communities. The low level of awareness in the reports could be due to the complexity associated with definition of the term 'awareness' in monitoring activities. This could involve covering what people were told in advocacy messages about children's rights, what people spontaneously accept and practice in communities as they raise children, what is debated and still needs emphasis are aspects of the message that are considered inapplicable in the African or specific country context. Hence, there was no reporting on levels of awareness of rights even among adults by these countries. The coverage of awareness raising activities was difficult to establish. What came out as common in all Country reports was that children's rights were adopted into National legislative systems and education curricula as illustrated in [86]. This has not impacted the lives of children in Africa [87, 88] though programs like MDGs reveal some progress [89].

In some countries, IHRIC have proved effective in promoting protection of children's rights in some Countries. The first ombudsperson for children was established in Norway in 1981 was reported to have statutory powers to protect children and enforce their rights mediating between children at risk, parents and the state [90]. Thomas et al. [91] observed that the Wales Commissioner for children was an indispensable platform for voicing the rights of children and interests of children and young people in Wales. It handled complaints and pursued policy issues raised directly by children and young people. The profile of children and they were recognized as citizen rather than 'problem' [92]. This example promises that IHRIC in Africa could be facilitated to effectively fulfil their functions. However, it is doubtful that these institutions will be 'independent' since they have to be financially supported by governments. Institutions effectiveness depends on adequate resources and change in attitudes and beliefs towards children as well as networking with other key stakeholders that contribute to realization of children's rights. The political will to enforce children's rights was observed to be major factor in these countries.

African's diverse cultural experiences and history dictates the need to consider the different systems and layers within Africa when introducing new ideas and programs. As suggested by Rajagopal [93] Africa is not just a collection of states united by ideologies but there are hegemonic and counter-hegemonic forces that influence events at different levels challenging global governance. The drafting of the 
UNCRC, had inadequate contribution from African Countries. Later on, Nationals who represented States Parties in the process 'imposed' it onto local systems and structures as an authoritative policy prescription [94]. This was probably due to inadequate participation in the drafting process and capacity to adopt international legislation into local experiences. The differences in the needs, tasks and influences of people at various levels were not considered in accordance with the systems analysis [95]. Yet every level has a role to play to make children's rights a reality and the systems may not function properly without contribution from all parts. There seem to have been an oversight about the influence of cultural traditions in the process of introducing change regarding the value of children in social cultural values of the people in the process.

As revealed by key stakeholders in the implementation process there was inadequate mobilization of traditional leaders and other key stakeholders who uphold values in the community to spearhead UNCRC implementation. This seems to have affected the level of awareness across the population in Uganda and other African countries. Awareness was also reported as a critical gap in Nigeria [96]. It was suggested that effective and systematic implementation of the UNCRC would have led to achieving wider acceptance of children's rights. Even with adoption of rights into legislations, it was important that constructive engagement with traditional leaders at local level be obtained. Local legislation was considered priority above social mobilization which would have ensured better understanding and ownership of UNCRC. Children's rights and CRC implementation remained a technical/ legal issue, rather than a continuous social legislative process. Moreover, development programs for children seem to be implemented without ensuring awareness of their objectives for children and other people that are directly affected as actors and beneficiaries. Hence, institutionalization of practices and positive change in behavior regarding upholding children's rights has remained a challenge.

The study found those children's rights awareness-raising activities were generally ad hoc and one-off activities. Country reports barely had any information about the levels on awareness and coverage at States Parties level. In all Countries there was no mention of processes through with the UNCRC was discussed and understood in the context of States Parties culture and traditions. It could be urged that the UNCRC suffered the inherent challenges of a top-down implementation procedure [97]. Major stakeholders including children were neglected and the processes lacked adequate monitoring and coordination support. What was revealed in this study also was that there seem to be limited consultation and participation of stakeholders in developing awareness raising activities. This confirmed Kuyini's [98] work that African countries overlook children and issues that concern them in the development of policies and programs. Children's rights are a development concern just like women's participation in development [99]. It would be necessary therefore to learn from strategies that have been used to access rights for marginalized and vulnerable people. This further suggests that more preparation was required in implementation of the UNCRC 1989, than just presenting new ideas. Stakeholder participants needed to reflect on what culture offered in relation to children's rights through dialogue; building on what was already known and practiced. This process would have enabled new ideas about children's rights to be appreciated while dangerous /negative practices in the traditions would be easily isolated and gradually discarded. For instance, traditional and cultural practitioners (witchdoctors) have been instrumental in the management of HIV/AID in Uganda after getting the right messages from implementers. Consultation, training, monitoring and reporting improves collaboration with traditional and cultural leaders. Appropriate and acceptable alternatives to practices need to be identified through this conscientization process suggested by Paulo Friere [100]. The use of action research approaches during field research in Uganda was a successful demonstration of how development agencies could engage with children, parents, guardians and community leaders and solicit their views to develop meaningful plans and programs.

\section{Implications}

States Parties in Africa have more than one HRIC implementing the UNCRC 1989 which serves to fulfill some of the functions as mandated. Their operations should not be limited to what is given in the Paris Principles 1993 because of the unique challenges in their local set-up Africa. Institutions can be allowed some independence that makes them efficient while taking care of the interests of the states parties for their children. This works well with coordination of stakeholders in the states parties. This could also be a major function of the IHRIC because of the nature of children's rights and the benefits coordination would bring to the process.

The article confirms that children have capacity to contribute to what communities consider to be important as lived rights. However, children's potential to attain rights and contribute to realization of children's rights for other children still has to survive the challenges of power relations that are engraved within the social systems and structures. This still highlights the need for representation by 'converted' adults with interest to protect children's rights at critical points. There are roles expected to be fulfilled by stakeholders at various transition stages of their involvement until children attain full capacity as was suggested by [101, $102,103,104$, and 105]. While recognizing and encouraging children who may be exceptionally brilliant, there is also need to be wary of children's ideas that may be completely unrealistic and to guide them appropriately aiming at protecting their future rights as was observed by Fortin [106] and Smith [107].

Moreover, inadequate appreciation of engaging with children was observed in the field among key stakeholders. 
Therefore, capacity needs to be built among implementers at all levels. Engaging with children needs to be well understood to be well organized, and reflected in plans and budgets of the IHRIC giving specific costing of intended activities and financiers that it is a worthwhile investment. We need to bear in mind also that the events with children and communities are always unpredictable. Therefore, appropriate preparation for employing the Action research approaches that generates children's ideas and experiences for inclusions in policies and programmes as suggested by Lester [108] requires skills and time. Some activities and programs may be difficult to plan and budget for which could be a capacity gap among IHRs personnel.

Furthermore, since children have the capacity to influence decisions and discussions that contribute to planning and policy but lack opportunity to participate. Moreover, activities for children seem to be ad hoc and fragmented with no continuity. An effective IHRIC could coordinate stakeholders including children, to improve programs for children. This institution should also be accessed by children to present their concerns, and engage with children to enlighten them about their rights as well as soliciting their views during planning and policy making activities as important aspects in the implementation of the UNCRC1989. Involving children was reported to a challenge due to structural challenges and unclear mandates of these institutions as well as inadequate budgetary allocations and capacity among staff to engage with children.

\section{Recommendations}

Experiences of States Parties regarding establishment of IHRIC, strongly suggests inadequate awareness about the goal of UNCRC and the importance of ensuring realization of children's rights. The observed challenges also suggest that IHRIC in Africa will take long to operate independently. Effectiveness in improving the lives of children does not seem to be one of the expectations of governments from these Institutions. All Country reports revealed inadequate financial allocations to enable them to perform their roles. States Parties need to focus on establishing systems that work in response to the commendations of the Committee on the Rights of the Child. The IHRIC should work to support and ease the implementation of the UNCRC. Even if having an institution in name is meant to serve as a beginning stage, then intentions for consolidation of processes should be reflected in reports with clear timelines on when to be implemented. Uganda and other African Countries with similar structural challenges should revitalise children's rights awareness raising activities for all stakeholders including children. Key implementers need to discuss international legislations in relation to their local settings so that they are in positions to respond to community needs appropriately.

Furthermore, other African Countries need to strengthen IHRICs to harmonize children's rights interventions and to ensure realization of children's rights. Activities for children should be monitored and reported on, while capacity building needs to be regular for all implementers to give opportunity for reflection on the process for improvement and introduction of new concepts.

\section{Conclusions}

This article discussed issues that could explain the challenge of African Countries to adequately implement the UNCRC through IHRICs. The conviction about the importance and function of the institution was observed as a major factor. Involving children as stakeholders in fulfilling children's rights by contributing to plans and policy development has been explored. Awareness of children's rights activities should be redesigned taking into consideration the African traditional values [109], as well as bringing on board traditional leaders as key children's rights stakeholders. Implementers should be wary of the dangers of conflicting with traditional leaders who may be interested in some aspects of culture and traditions that violate children's rights. Stakeholders in implementation need to engage people in reflexive intercultural dialogue to reach consensus on what is good for children. Involvement of cultural leaders would ease the task of isolating harmful traditional practices, while promoting children's rights that support African values.

Children's rights awareness raising activities should be organized for officers in policy making positions so that activities initiated for children and with children at lower levels are positively perceived and supported. Furthermore, children's rights awareness activities in States Parties should be well planned, implemented, monitored and reported on periodically as a key process aspect of UNCRC implementation and realization of children's rights. Planning process should ensure that children are consulted and meaningfully involved in appropriate processes.

Realization of children's rights endeavors could benefit from mobilization approaches that have been applied in reaching the 'hard to reach' categories of the population with development messages as well as consultations. The recommendation of establishing IHRIC was clear demonstration that children need effective representation in every country. Representation out of conviction about the plight of children requires closer interaction and engagement aimed at making children key actors in protection of their rights. Participation in programming empowers children to gain more control of their lives. Participatory approaches are therefore, highly recommended for working with children.

Political will and national stability are also key aspects in ensuring protection of children's rights. Stakeholders should not lose sight of the experiences of children that translate into rights abuse when promoting the international Convention on the Rights of the Child. States parties have a critical responsibility of addressing poverty which seems to be a root cause for unfulfilled rights. 
Finally, this article suggests that including children in issues that affect them in all aspects of life is not an option. There is need for capacity building among stakeholders so that they recognize children's contribution in their activities for effectiveness and sustainability of good practices and change in behavior. Adults need to appreciate that equality should be accorded to everyone whether they are young or dependent of the state through the use of social services.

\section{Acknowledgements}

This article is based on the study conducted for a $\mathrm{PhD}$ that was partially sponsored by the University of Central Lancashire, Preston UK. I benefited from the guidance and supervision of the University staff. The British Institute in Eastern Africa (BIEA) contributed to the fieldwork process. I paid half of my tuition and maintenance in UK. I am indebted to my family for supporting me throughout especially during fieldwork in Uganda.

\section{REFERENCES}

[1] UNITED NATIONS HUMAN RIGHTS (UNHR) Office of the High Commissioner, General Comments $\mathrm{CRC} / \mathrm{GC} / 2002 / 2$

[2] Freeman, M. (2000) The future of children's Rights. Children and society Volume 14 (2000) pp. 277-293. John Wiley and Sons, Ltd.

[3] Freeman, M. (2000) The future of children's Rights. Children and society Volume 14 (2000) pp. 277-293. John Wiley and Sons, Ltd.

[4] Thomas, N. (2002) Children, Family and the State. Decision-making and Child Participation. Bristol: The Policy Press.

[5] Archard, D. (2004) Children: Rights and Childhood (2 ${ }^{\text {nd }}$ Ed.) London: Routledge.

[6] Mulinge, M. (2002). Implementation of the 1989 United Nations Convention on the Rights of the Child in Sub-Saharan Africa: the overlooked social economic and political dilemmas. Child Abuse and Neglect 26, 1117-1130.

[7] Doek, J., E. (2011) Convention on the Rights of the Child: achievements and Challenges: combat Law: The Human Rights magazine Volm3, Issue 1: Children's Rights.

[8] Cheney, Kristen, E. (2013) Killing them softly? Using children's rights to empower Africa's orphans and vulnerable children. International Journal of Social Work 56 (1) 92-102 SAGE

[9] UNITED NATIONS HUMAN RIGHTS (UNHR) Office of the High Commissioner, UNCRC 1989, www.ohchr.org

[10] A/RES/48/134 85 ${ }^{\text {th }}$ Plenary meeting 20 ${ }^{\text {th }}$ Dec.1993. Paris Principle 1993. www.un.org/documents/ga/res/48r134.htm

[11] UNICEF. (June 2001). Independent Institutions Protecting
Children's Rights. Innocenti Digest no. 8, Innocenti Research Centre, Florence, Italy.

[12] Gran, B \& Aliberti Dawn. (2003) the office of the children's Ombudsperson: children's Rights and Social-Policy Innovation. International Journal of the Sociology of Law 31(2):89-106 Department of Sociology Case Western Reserve University Cleveland USA

[13] Thomas, N., Cook, M., Cook, J., France, A., Hillman, J., Jenkins, C., Pearson, Toby., Pugh-Dungey, R., Sawyers, B., Taylor, Matthew, T., Crowley, A. (2010) Evaluating the children's Commissioner for Wales: Report of a participatory Research Study International Journal of Children's Rights 18 (2010) 19-52 MARTINUS NIJHOFF

[14] Thomas, N., Gran, B., and Hanson, K. (2011) An Independent voice for Children's rights in Europe? The role of Independent children's rights Institutions in the EU. International Journal of Children's Rights; 19(2011) p. $429-$ 449.

[15] UNICEF. (2013). Championing Children's Rights. A global study of independent human rights institutions for children. UNICEF Office of Research, Florence, Italy.

[16] Murray, R and De Beco, G (2015) Commentary on the Paris Principles on National Human Rights Institutions Cambridge University Press

[17] Sabatier. (1986) Top-down and bottom-up Approaches to implementation research: A critical Analysis and suggested synthesis. Journal of Public Policy Volume 6 Issue 1 Cambridge University Press.

[18] Munroe, Pinkerton, J., Mendes, P., Hyde - Dryden, G., Herczog, M., Benbenislity, R. (2011). The contribution of the United National Convention on the Rights of the child to understanding and promoting the interests of young people making the transition from Care to adulthood. Children and youth service Review 33 (2011) 17 - 24. Elsevier .com

[19] Rajagopal Balakrishnan. (2006) Counter-Hegemonic International Law: Rethinking Human Rights and Development as a Third World Strategy. Third World quarterly Volume 27 No. 5. Reshaping Justice: International Law and the Third World. Taylor \&Francis Ltd.

[20] Munroe, Pinkerton, J., Mendes, P., Hyde - Dryden, G., Herczog, M., Benbenislity, R. (2011). The contribution of the United National Convention on the Rights of the child to understanding and promoting the interests of young people making the transition from Care to adulthood. Children and youth service Review 33 (2011) 17 - 24. Elsevier .com

[21] Sabatier. (1986) Top-down and bottom-up Approaches to implementation research: A critical Analysis and suggested synthesis. Journal of Public Policy Volume 6 Issue 1 Cambridge University Press.

[22] Andrea, S. (2014) From the global to the Local. How International rights reach Bangladesh's children. Routledge UK Taylor and Francis Group

[23] O’Neill, O. (1988). Children's rights and children's lives. In Harry and Adam. Justice for Children. Autonomy Development and the State. State University of New York Press.

[24] Davidson, H. (2014) Does the UN CONVENTION on the Rights of the child Make a difference? Michigan State 
International Law Review Volume 22. No. 2 pp. 497-523

[25] O’Neill, O. (1988). Children's rights and children's lives. In Harry and Adam. Justice for Children. Autonomy Development and the State. State University of New York Press.

[26] Mulinge and Munyae, M. (2002) Implementation of the 1989 United Nations Convention on the Rights of the Child in Sub -Saharan Africa: the overlooked socioeconomic and political dilemmas. Child Abuse and Neglect 26, 1117-1130.

[27] World Bank. (2013). World Development Indicators. Uganda Demographic and Health Survey, 2011.New York.

[28] Africa Child Policy Forum (ACPF) (2014) Africa Report on Violence Against Children. Addis Ababa

[29] Steward, R. (2009) 'Child Participation and Independent Human Rights Institutions for Children in Europe'. Innocenti Working Paper No. 2009:23, UNICEF Innocenti Research Centre, Florence.

[30] Thomas et al. (2010) Evaluating the Children's Commissioner for Wales: Report of a participatory Research Study. International Journal of Children's Rights 18(2010) 19-52. MARTINUS NIJHOFF

[31] Himonga, Himonga. (1998) "Law and Gender in South Africa: Human Rights and Family Law." In The Changing Family: International Perspectives. Eekelaar and T. Nhlapo edited. Oxford: Hart Publishers

[32] Mokgoro Y., Justice. (1998)'Ubuntu and the law in South Africa. Baffalo Human Rights Law Review 2 - 15.

[33] Ncube,W. (1998). 'The African Cultural Fingerprints? The changing Concepts of Childhood' in Ncube W (edited). Aldershot and Brookfield Ash gate.

[34] Mulinge and Munyae, M. (2002) Implementation of the 1989 United Nations Convention on the Rights of the Child in Sub -Saharan Africa: the overlooked socioeconomic and political dilemmas. Child Abuse and Neglect 26, 1117-1130.

[35] UNICEF. (2009). 20 years of the UNCRC http://www.unicef.org/rightsite accesses on 17/05/2012.

[36] UNICEF. (2014)THE STATE OF THE WORLD'S CHILDREN 2014 IN NUMBERS. EVERY CHILD COUNTS- Revealing Disparities, Advancing Children's rights at www.unicef.org/sowc 2014/number accessed on $05 / 06 / 2015$

[37] Kuyini, A.B. (2005), Implementing Child Rights Protection Law in Ghana: A case study http://www.cevsghana.org/yaho o site admin/assets/doc accessed on 05/07/2012 University of $\mathrm{New}$ England, Australia.

[38] UNICEF. (2014)THE STATE OF THE WORLD'S CHILDREN 2014 IN NUMBERS. EVERY CHILD COUNTS- Revealing Disparities, Advancing Children's rights at www.unicef.org/sowc 2014/number accessed on $05 / 06 / 2015$

[39] Mulinge and Munyae, M. (2002) Implementation of the 1989 United Nations Convention on the Rights of the Child in Sub -Saharan Africa: the overlooked socioeconomic and political dilemmas. Child Abuse and Neglect 26, 1117-1130.

[40] Steward, R. (2009) 'Child Participation and Independent
Human Rights Institutions for Children in Europe'. Innocenti Working Paper No. 2009:23, UNICEF Innocenti Research Centre, Florence.

[41] O'Neill, O. (1988). Children's rights and children's lives. In Harry and Adam. Justice for Children. Autonomy Development and the State. State University of New York Press.

[42] Doek, J., E. (2011) Convention on the Rights of the Child: achievements and Challenges: combat Law: The Human Rights magazine Volm3, Issue 1: Children's Rights.

[43] Cheney, Kristen, E. (2013) Killing them softly? Using children's rights to empower Africa's orphans and vulnerable children. International Journal of Social Work 56 (1) 92-102 SAGE

[44] Davidson, H. (2014) Does the UN CONVENTION on the Rights of the child Make a difference? Michigan State International Law Review Volume 22. No. 2 pp. 497-523

[45] Korbin, E., J. (1983) Child abuse and Neglect: cross-cultural perspectives. University of California. downloaded on www.ucpress.educ 29/05/2015

[46] Federle, K. (1994). Rights flow downhill. International Journal of Children's Rights. Pg. 343 in Thoko Kaime (2011). The Convention on the Rights of the Child. A cultural Legitimacy Critique. Europa Law Publishing. Amazon.

[47] Mulinge and Munyae, M. (2002) Implementation of the 1989 United Nations Convention on the Rights of the Child in Sub -Saharan Africa: the overlooked socioeconomic and political dilemmas. Child Abuse and Neglect 26, 1117-1130.

[48] Mulinge and Munyae, M. (2002) Implementation of the 1989 United Nations Convention on the Rights of the Child in Sub -Saharan Africa: the overlooked socioeconomic and political dilemmas. Child Abuse and Neglect 26, 1117-1130.

[49] UNICEF. (2009). 20 years of the UNCRC http://www.unicef .org/rightsite accesses on 17/05/2012.

[50] UNICEF. (2014)THE STATE OF THE WORLD'S CHILDREN 2014 IN NUMBERS. EVERY CHILD COUNTS- Revealing Disparities, Advancing Children's rights at www.unicef.org/sowc 2014/number accessed on $05 / 06 / 2015$

[51] Smith, A.B. (2007) Children as Social Actors: An Introduction .The Journal of Children's Rights, 15 (2007)1 4. Children issues Centre, University of Otago. Koninklijke Brill NV, Leiden.

[52] Thomas, N. (2001). Listening to children: in Children in Society. Contemporary Theory, Policy and Practice. Pam Foley, Jeremy Roche and Stanley Tucker (edited). Palgrave in Association with Open University.

[53] Fortin, J. (2006) Accommodating children's Rights in a post have Rights Act Era. Modern Law Review. Volume 69. Issue 3. Pg 299- 326. Wiley online Library.

[54] Lee, E., T. (1999) 'Children's Rights and the Problem of Equal respect,'- Hofstra Law Review: Volm27 iss.4, Article 4 available at http://scholarlycommons.law.hofstra.edu/hlr vol27/iss $4 / 4$

[55] Hanson, K. and Nieuewenhuys, O. (2013) Reconceptualised children's rights in International Development. Living rights, social Justice Transitions, Cambridge University Press. 
pp.323-352

[56] Lundy, L. (2007) 'Voice is enough' Conceptualising Article 12 of the United Nations Convention on the Rights of the child, "British Educations Research Journal 33(6) pg.927-942

[57] Acharya, Lalatendu. (2010) Child reporters as agents of change. In A Handbook for Children and Young People's Participation. Perspectives from theory and practice. (Edited) Barry Percy-Smith and Nigel Thomas. London: Routledge.

[58] Hart, R.A. (1992). 'Children's Participation from tokenism to citizenship' Innocenti

[59] Acharya, Lalatendu. (2010) Child reporters as agents of change. In A Handbook for Children and Young People's Participation. Perspectives from theory and practice. (Edited) Barry Percy-Smith and Nigel Thomas. London: Routledge.

[60] Creswell, J.W. (1998, 2007) Qualitative Inquiry and Research Design: Choosing among five traditions (Second edition), Sage Publication, London.

[61] Groenewald, T. (2004) A phenomenological research design illustrated. International Journal of Qualitative Methods, 3 (1) Article 4. Retrieved 12/06/2015 from http://www.ualberta.ca /-iiqm/backissue/3_htm/groenewald.html

[62] Lester, S. (1999). An Introduction to Phenomenological Research, Taunton UK, Stan Lester Developments. www.sld.demon.co.uk/resmethy.pdf. (p. 1-4) (accessed on 23/05/2013).

[63] Government of Uganda (GOU) (2013) The State of Uganda's Children Report 2013. Kampala.

[64] Camfield, L., Crivello, G., Woodheed, M. (2008) Wellbeing Research in Developing Countries. Reviewing the role of Qualitative methods Social Indicators Research. Springer Science and Business Media June 2009. Volume 90. Issue 1 pg, $5-31$

[65] Barbour, R.S. (2007). Doing Focus Groups. The Sages Handbook of Qualitative Methods in Health. Edited by Ivy Bourgealt, Robert Lingwall, Ray de Vviles. London.

[66] Manson, J.(2002) Qualitative Researching (second edition) SAGE Publishing

[67] Chambers, R. (1997) Whose Reality Counts? Putting the First Last. IDS

[68] Rizzini, I., and Thapliyal, N. (2007) 'Young People's Perceptions and Experience of Participation in Rio de Janeiro, Brazil' Children, Youth and Environment 17(2): 74-92 retrieved 09/10/2014 htt://www.Colorado.educ/journals/cyc

[69] United Nations General Assembly. (1989) Adoption of the Convention on the Rights of the Child (CRC). New York: United Nations.

[70] Gibbs, G. (2007) Analysing Qualitative Data. The SAGE Qualitative Research Tool Kit.Los Angeles Sage Publication.

[71] United Nations, CRC/C/NAM/Q/2-3/ Add.1 2012 periodic report to the UN Committee on the Rights of the Child viewed Dec 2012, fromwww.ohchr.org/Documents.Country/Namibi a

[72] United Nations, $\mathrm{CRC} / \mathrm{C} / \mathrm{GHA} / \mathrm{CO} / 2 / 2006$ 2rd periodic report to the UN Committee on the Rights of the Child viewed June 2012, from www.ohchr.org/Documents.Country/Ghana
[73] UNICEF. (2013). Championing Children's Rights. A global study of independent human rights institutions for children. UNICEF Office of Research, Florence, Italy.

[74] Mauritius NGO Second Periodic Report. (2006) covering 1995-2006 crin.org/en/library/countries

[75] United Nations, CRC/C/BDI/CO/2, Oct. 2010 Burundi's 2nd periodic report to the $\mathrm{UN}$ Committee on the Rights of the Child viewed April 2012, from www.ohchr.org/ Documents. Country/Burundi

[76] United Nations, CRC/C/OPSC/SDN/CO/1/ $21^{\text {st }}$ June 2007 periodic report to the UN Committee on the Rights of the Child viewed Nov. 2012, from www.ohchr.org/Documents. Country/Sudan

[77] Swaziland NGO report $1^{\text {st }}$ periodic report. (2006) 43 session crin.org/en/library/countries

[78] United Nations, CRC/C/SR.1058 2005 periodic report to the UN Committee on the Rights of the Child viewed May 2012, from www.ohchr.org/Documents.Country/

[79] Uganda Child Rights NGO Network (UCRNN) (1997) Uganda NGO response to the country report. crin.org/en/libr ary/countries

[80] United Nations, CRC/C/UGA/CO/2/ Nov. 2005 periodic report to the UN Committee on the Rights of the Child viewed May 2012, from www.ohchr.org/Documents.Country/Ugand a

[81] Liberia Non- Governmental Organisation (NGO) report (2003) CRC/C/LIB/3/2003

[82] United Nations, CRC/C/NIG/4, 2010, Nigeria's periodic report to the UN Committee on the Rights of the Child, viewed January 2014, from www.ohchr.org/Documents/Cou ntry/Nigeria.

[83] United Nations, CRC/C/AGO/CO/2-3, Oct. 2010 Angola's $2^{\text {nd }}$ and $4^{\text {th }}$ periodic report to the UN Committee on the Rights of the Child viewed May 2012, from www.ohchr.org/Docum ents. Country/Angola

[84] Cheney, Kristen, E. (2007). Pillars of the Nation: Child Citizens and Ugandan National Development. Chicago, IL, University of Chicago Press, USA.

[85] Andrea, S. (2014) From the global to the Local. How International rights reach Bangladesh's children. Routledge UK Taylor and Francis Group

[86] Doek , J., E.(2007) The Best Interest of THE CHILD Harmonisation of national laws with the Convention on the Rights of the Child: Some observations and suggestions. The African Child Policy Forum. Addis Ababa.

[87] UNICEF. (2009). Celebrating 20 years of the Convention on the Rights of the Child. New York. accessed on 12/06/2012

[88] Mulinge and Munyae, M. (2002) Implementation of the 1989 United Nations Convention on the Rights of the Child in Sub -Saharan Africa: the overlooked socioeconomic and political dilemmas. Child Abuse and Neglect 26, 1117-1130.

[89] World Bank. (2013). World Development Indicators. Uganda Demographic and Health Survey, 2011.New York.

[90] Gran, B\&Aliberti Dawn. (2003) the office of the children's 
Ombudsperson: children's Rights and Social-Policy Innovation. International Journal of the Sociology of Law 31(2):89-106 Department of Sociology Case Western Reserve University Cleveland USA

[91] Thomas, N., Cook, M., Cook, J., France, A., Hillman, J., Jenkins, C., Pearson, Toby., Pugh-Dungey, R., Sawyers, B., Taylor, Matthew, T., Crowley, A. (2010) Evaluating the children's Commissioner for Wales: Report of a participatory Research Study International Journal of Children's Rights 18 (2010) 19-52 MARTINUS NIJHOFF

[92] Thomas, N., Cook, M., Cook, J., France, A., Hillman, J., Jenkins, C., Pearson, Toby., Pugh-Dungey, R., Sawyers, B., Taylor, Matthew, T., Crowley, A. (2010) Evaluating the children's Commissioner for Wales: Report of a participatory Research Study International Journal of Children's Rights 18 (2010) 19-52 MARTINUS NIJHOFF

[93] Rajagopal Balakrishnan. (2013) Right to Development and Global Governance: Old and New Challenges Twenty-Five Years On. Human Rights Quarterly 35 No. 4 873-909. Johns Hopkins University Press.

[94] Koontz and Newig (2014) Top-down and Bottom-up Approaches for Collaborative Watershed management. Policy Studies Journal 42 (3) 416-443

[95] Bronfenbrenner, U. (1986) 'Ecology of the Family as a Context for Human Development: Research Perspectives'. Development Psychology, Vol. 22. Pp. 732 - 42 cited in Bettby,

[96] United Nations, CRC/C/NIG/4, 2010, Nigeria's periodic report to the UN Committee on the Rights of the Child, viewed January 2014, from www.ohchr.org/Documents/Cou ntry/Nigeria.

[97] Sabatier. (1986) Top-down and bottom-up Approaches to implementation research: A critical Analysis and suggested synthesis. Journal of Public Policy Volume 6 Issue 1 Cambridge University Press.

[98] Kuyini, A.B. (2005), Implementing Child Rights Protection Law in Ghana: A case study http://www.cevsghana.org/yaho o_site_admin/assets/doc accessed on 05/07/2012 University of New England, Australia.
[99] Alanen, L. (2005) Women's Studies /Children's Studies: Parallels, links and perspectives, in Children Taken Seriously in theory, Policy and Practice, Mason, J. and Fattore T, Jessica Kingsley Ltd., London, pp. 31-45

[100] Freire, P. (1970) Pendagogy of the Oppressed. New York: Herder and Herder

[101] Lee, E., T. (1999) 'Children's Rights and the Problem of Equal respect,'- Hofstra Law Review: Volm27 iss.4, Article 4 available at http://scholarlycommons.law.hofstra.edu/hlr vol27/iss $4 / 4$.

[102] Freeman, M. (1997). The moral Status of Children: Essays on the Rights of the Children. The Hague. Martinus Nijhoff Publishers.

[103] Reynold, P.,O. Nieueuwenhuys and Hanson, K., (2006) Refractions of children's Rights in Development Practice: A view from Anthropology Introducing Childhoods 13(3) 291-302

[104] Casas, Ferran; Saporiti, Angelo; Gonzalez, Monica; Figuer, Cristina. (2006). Children's Rights from the point of View of Children, Their Parents and Their Teachers: A Comparative Study between Catalonia (Spain) and II Molise (Italy). The International Journal of Children's Rights 14: 1-75, 2006.

[105] Steward, R. (2009) 'Child Participation and Independent Human Rights Institutions for Children in Europe'. Innocenti Working Paper No. 2009:23, UNICEF Innocenti Research Centre, Florence.

[106] Fortin, J. (2006) Accommodating children's Rights in a post have Rights Act Era. Modern Law Review. Volume 69. Issue 3. Pg 299- 326. Wiley online Library.

[107] Smith, A.B. (2007) Children as Social Actors: An Introduction. The Journal of Children's Rights, 15 (2007)1 4. Children issues Centre, University of Otago. Koninklijke Brill NV, Leiden.

[108] Lester, S. (1999) An Introduction to Phenomenological Research, Taunton UK, Stan Lester Developments. www.sld.demon.co.uk/resmethy.pdf. (p. 1-4) (accessed on 23/05/2013).

[109] Obeng, C. (2009) Children's Health in a Traditional Society. New York Nova Science Publishers. 